\title{
Impact of IPPC Scenarios on indoor environment quality of historic buildings
}

\author{
Jan Weyr ${ }^{1, *}$, Richard Kalný ${ }^{1}$, and Jiř́ Hirs ${ }^{1}$ \\ ${ }^{1}$ Brno University of Technology, Faculty of Civil Engineering, Veveři 331/95, Brno 602 00, Czech Republic
}

\begin{abstract}
Ensuring proper indoor environment quality in buildings with historic value or buildings located in historic centres of cities is not an easy task. These buildings are frequently listed in historic preservation lists; thus, the amount of possible refurbishment methods is significantly limited due to increased protection. This article deals with comprehensive analysis of internal microclimate of a multi-purpose building located in the historic centre of Prague during summer period. Possible refurbishment methods permitted by the National Heritage Institute are analysed and compared using building energy performance simulation tool BSim in order to achieve proper working conditions in offices in the building. Structural and technical modifications are proposed in order to optimize the amount of solar heat gains leading to reduction of overheating and increase of energy efficiency. Furthermore, two global warming projections from the Fourth Assessment Report of Intergovernmental Panel on Climate Change are applied to the current weather data to examine the impact of the global climate change on the building. As expected, the cooling demand increases with the climate change scenarios presenting more difficult challenges to maintain the indoor environment quality within the limitations given by the legislation.
\end{abstract}

\section{Introduction}

Ensuring the optimal indoor environment quality in buildings with historic value or buildings located in historic centres of cities or protected zones is not an easy task. In many cases, the function of these historical buildings especially inside the bigger cities has changed significantly over last decades. Older buildings in historic centres of many Czech cities now serve as public spaces, shops, offices, restaurants, etc. Therefore, the requirements of indoor environment quality have to be met, however these buildings are frequently listed in historic preservation lists, thus the amount of possible refurbishment methods is significantly limited [1]. There are different evaluation tools developed to assess the condition of different types of buildings and living conditions of occupants, such as EPIQR (Energy Performance Indoor Environmental Quality Retrofit) [2]. Changed purpose of a building leads not only to different requirements, but often also to change of heating and cooling loads, change of operation or behaviour of occupants.

This work not only aims at problematic of ensuring proper working conditions in a historic building with changed function with limited retrofit possibilities at present time, but also focuses on outlook taking the Intergovernmental Panel on Climate Change (IPCC) scenarios into consideration.

The IPCC is an international body established by the World Meteorological Organization (WMO) and United
Nations Environment Programme (UNEP) to assess the state of knowledge of all the aspects of climate change issue and to provide policy-makers with an objective source of information about the causes of climate change, potential environmental and socio-economic impacts and to discuss possible response options. The IPCC does not produce or carry its own research or monitor climate change. The IPPC's assessments and reports are based on published literature, which includes both peer-reviewed and non-peer-reviewed scientific sources [3].

The IPPC has produced five reports reviewing the latest knowledge about climate state and science and special reports on specific topics.

The global warming projections were published in 2007 in the Fourth Assessment Report (AR4) [4]. The projection shown the estimation to the end of $21 \mathrm{st}$ century relative to temperatures at the end of the 20th century (1980-1999). Additionally, there are descriptions of the greenhouse gas emissions scenarios in Special Report on Emission scenarios. The global warming projections from AR4 are shown in the figure below (Fig. 1) with the upper and the lower limit of "likely" scenarios and the best possible estimate. "Likely" means greater than $66 \%$ probability of being correct, based on expert judgement.

The A1 scenario family describes a future world with a very rapid economic growth, the global population peaking in mid-century and declining thereafter. This

* Corresponding author: jan.weyr@vutbr.cz 
scenario family also expects the rapid introduction of new and more efficient technologies.

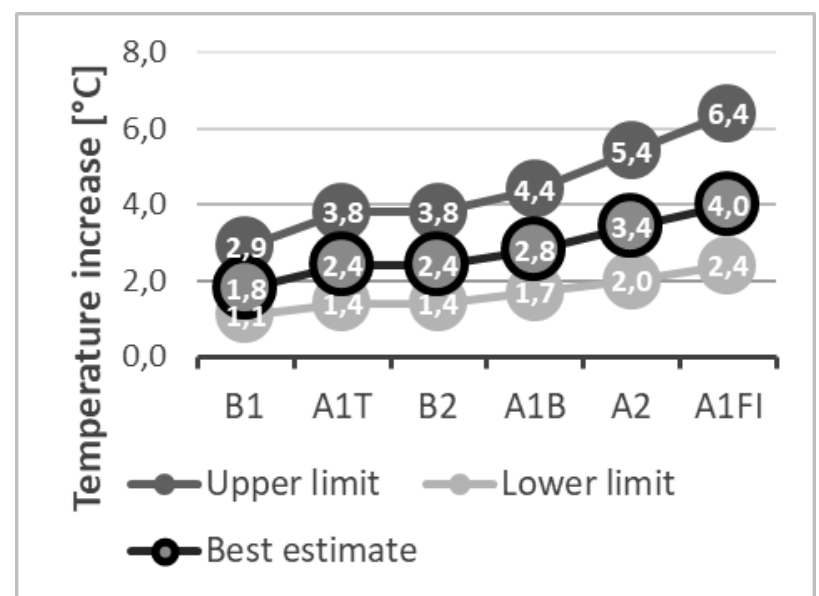

Fig. 1. Temperature increase based on the global warming projections from AR4

The A1 scenario family is subdivided into three groups distinguished by their technological emphasis: the fossil intensive (A1FI), on non-fossil energy sources (A1T), or a balance across all sources (A1B - where balanced is defined as not relying too heavily on one particular energy source). The A2 scenario presents a very heterogeneous world. The focal theme of this scenario is preservation of local identities and selfreliance of the local bodies with continuous increase of the global population and with technological change more fragmented and slower than the other storylines. The B1 storyline describes the same trend in the global population as the scenario A1 but with rapid change of economy towards services and information structures, with reduction of material consumption and the introduction of clean and resource-efficient technologies. The underlying theme of this scenario is an emphasis on global solutions to economic, social and environmental topics. The B2 storyline and scenario family describes a world in which the emphasis is on local solutions to economic, social and environmental sustainability. The global population increase is continuous throughout the whole examined period but at a rate lower than the scenario A2. There are intermediate levels of economic development, and less rapid and more diverse technological change than in the A1 and B1 storylines. This scenario is also oriented towards environmental protection and social equity with focus on local and regional levels.

\section{Aims}

The first objective of this work is to present a case study of simplified indoor environment quality analysis in a historic building located in the centre of a historical city of Prague. This city part is a protected zone with very limited number of possible retrofit measures for all the buildings located inside the historic centre of the Czech's capital city.

The experimental part of the work deals with longterm measurements and comprehensive analysis of room air temperatures and relative indoor humidities and over two summer periods (2016 and 2017) in the multipurpose building facing Václavské náměstí (Wenceslas Square) in Prague. The owner of the property has long been addressing the problem of building overheating during the summer season and the high-energy demand during the winter operation. The document describes and analyse energy saving measures, which should lead to reduction of external thermal loads in order to decrease room air temperatures in offices and commercial spaces. Furthermore, the calibrated building model is created in Danish software BSim to discuss and assess retrofit measures leading to lowering of cooling demand during hot summer periods. Because it is a large structure with many rooms, different structures and structural composition, the simplification of the model is a key component and is presented hereby. Finally, the change of energy demands after applying two IPCC scenarios from the Fourth Assessment Report (the scenario A1B and the scenario A2) is studied together with the influence of the changed climate on problem with overheating of the building.

\section{Building description}

\subsection{Building and building technologies}

The assessed building object is located in the upper part of Wenceslas Square in Prague, Czech Republic. The object is in private ownership and it is included in historic preservation list. It consists of the main part with 4 floors and the façade facing towards the area of Wenceslas Square and two side wings. Walls of the building are made of bricks and stone, floor structures in the main part are wooden, smaller parts of the object's floor structure in two side wings are made of cast-in-place reinforced concrete.

The object was built in the beginning of 19th century; the complete reconstruction was made in 1995. Furthermore, modernization of cooling devices and units was carried out; the old cooling unit was replaced by two cooling units with cooling power $176 \mathrm{~kW}(2 \times 88 \mathrm{~kW})$. Subsequently, the building management system (BMS) was upgraded to comply with the new units.

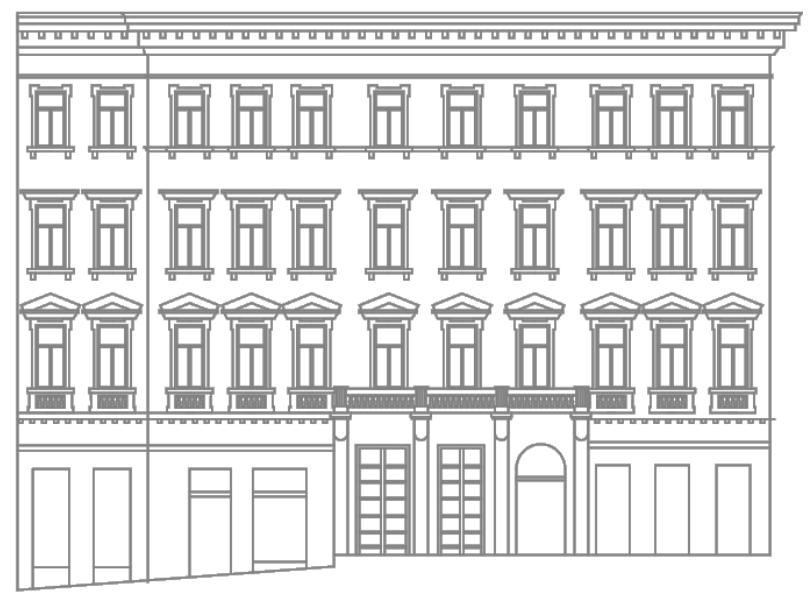

Fig. 2. Examined historic building - front façade 


\subsection{Description of refurbishments}

There were several problems leading to summer overheating of the building object. The building's operation has considerably changed during last 5 years with significant increase of internal heat loads from technologies. Due to its historic value, number of the possible refurbishment measures was limited. Application of external thermal insulation system and external shading of windows and building openings is not allowed; enlargement, extension and reconstruction of ventilation and cooling system is limited due to historic value of interiors.

Following measures were applied during summer period 2016 and 2017 to achieve proper working conditions in offices and conference rooms and to lower cooling demands of the whole building object:

- Resuming operation of the second cooling unit July 2016

- Installation of sun shading elements on the $4^{\text {th }}$ floor - August 2016

- Installation of roller blinds on the $1^{\text {st }}, 2^{\text {nd }}$ and $3^{\text {rd }}$ floor - August 2016

\section{Simulation model}

Simulations were carried out in software BSim 2002. BSim is based on law of conservation of energy and law of conservation of mass with calculations solved non-stationary. Heat is described by equations of heat balance, using heat balance formula for a zone:

$$
\Phi_{c o n}+\Phi_{w n d}+\Phi_{s o l}+\Phi_{s y s}+\Phi_{v n t}+\Phi_{i n f}+\Phi_{m i x}=0
$$

where $\Phi_{\text {con }}$ represents heat flows from adjoining constructions, $\Phi_{\text {wnd }}$ symbolises heat flows through windoors, $\Phi_{\text {sol }}$ solar radiation through windoors, $\Phi$ sys heat flows from air penetration from outdoor air (infiltration, venting), $\Phi_{\mathrm{vnt}}$ heat flows from air supplied from ventilation systems, $\Phi_{\text {inf }}$ stands for heat flows from air transferred from other zones, and $\Phi_{\text {mix }}$ heat flows based on an air exchange between thermal zones and spaces in the model [5].

\subsection{Building geometrical and calculation model}

The geometrical model (see Fig. 3) consists of 68 cells grouped into 5 zones according to the functional distribution of rooms and the setting of technical building services. The real number of rooms in the simulated building is 166; however, simplification of the model was introduced. Large number of rooms were coupled based on their function and volume of mutual air change to reduce computational complexity and time. The heat capacity of partition structures was covered within cell air heat capacity. Each zone was monitored at least with one thermo-hygrometer data logger with values stored to non-volatile memory.

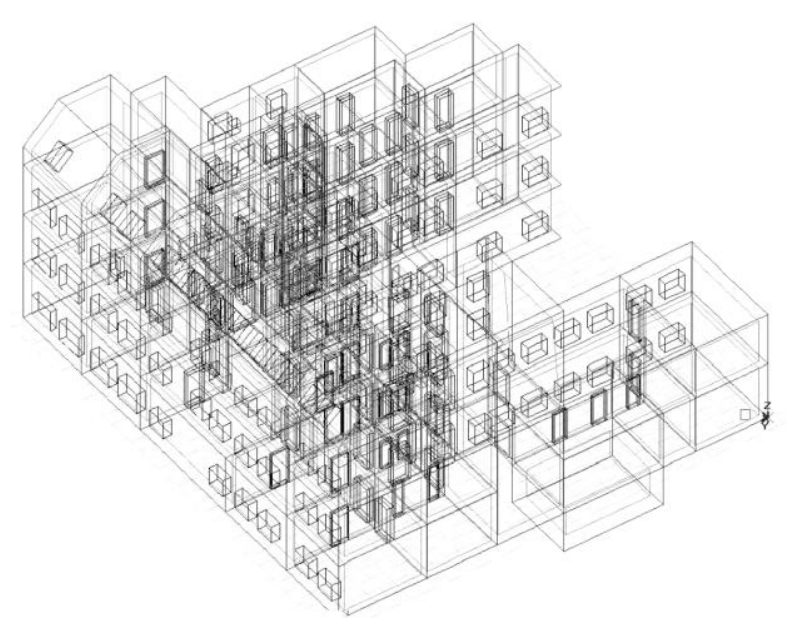

Fig. 3. Building geometrical model

In case of such a complicated historic building with different compositions and operation, the balance between simplification and detailed modelling is crucial. Example of the detailed approach can be found in the fourth floor, where we had to model accurately the bevelled edge of the roof due to excessive solar gains leading to overheating of attic offices (Fig. 4).

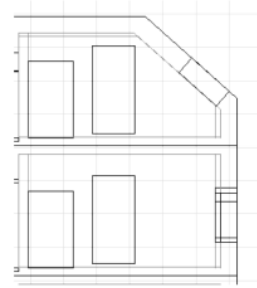

Fig. 4. Section detail of attic space

Distribution of heating and cooling power for both the calibration purpose and simulation purposes was based on configuration of the building management system (BMS), consultations with the operator of the examined building, and in situ inspections. Occupancy patterns and behaviour patterns were based on long-term monitoring of entries into the monitored building and electricity consumption.

Table 1. Basic parameters of building model

\begin{tabular}{|c|c|}
\hline Gross floor area & $2494 \mathrm{~m}^{2}$ \\
\hline Gross internal area & $1983 \mathrm{~m}^{2}$ \\
\hline Gross volume & $10467 \mathrm{~m}^{3}$ \\
\hline Net volume & $7172 \mathrm{~m}^{3}$ \\
\hline $\begin{array}{c}\text { Thermal conductivity of } \\
\text { peripheral walls }\end{array}$ & $0.42-0.68 \mathrm{~W} / \mathrm{m} . \mathrm{K}$ \\
\hline $\begin{array}{c}\text { Thickness of peripheral walls } \\
\text { Thermal conductivity of } \\
\text { windows }\end{array}$ & $400-1050 \mathrm{~mm}$ \\
\hline
\end{tabular}




\subsection{Weather data}

The data set of outdoor conditions for the calibration was obtained and adapted from measurements at the examined building and three weather stations located in the close vicinity of Wenceslas Square. Stations were selected according to several criteria. The most important thing was the distance from the building. The key characteristic was availability of solar radiation data and the accuracy of measurements. The character of the surrounding built-up area and credibility of the institute were also taken into account.

The focal objective of this work is to study influence of possible retrofit measures energy demands, behaviour of building technologies, and on indoor environment quality in this building. Furthermore, we wanted to study this behaviour for changed conditions within the climate change scenario storylines until 2100 from the IPCC report. For these purposes, the TMY (typical meteorological year) dataset based on local measurements from 1991 to 2010 were used and compared with results after application of A1B and A2 scenarios. The geometrical model, material properties, internal thermal gains, losses, and their scheduling are same in all variants.

\subsection{Altered parameters due to renovations}

To examine effect of possible retrofit measures, the following parameters of the cooling system, shading, and heat transmittance were modified in BSim simulations. They reflect the measures already physically carried out or measures planned in future. As mentioned in chapter 3, there is significant restriction of retrofit measures due to historic value of the building and the surrounding city quarter.

Table 2. Modified parameters

\begin{tabular}{|c|c|c|c|}
\hline ID & $\begin{array}{c}\text { Description of } \\
\text { retrofit } \\
\text { measure }\end{array}$ & $\begin{array}{c}\text { Finished / } \\
\text { Planned }\end{array}$ & $\begin{array}{c}\text { Model parameter } \\
\text { modification }\end{array}$ \\
\hline A & $\begin{array}{c}\text { Resumed } \\
\text { operation of } 2^{\text {nd }} \\
\text { cooling unit }\end{array}$ & $\begin{array}{c}\text { Finished } \\
2016\end{array}$ & $\begin{array}{c}\text { Increased cooling } \\
\text { power }-88 \text { to } 176 \\
\mathrm{~kW}\end{array}$ \\
\hline B & $\begin{array}{c}\text { Sun shading } \\
\text { elements } \\
\text { installation }-4^{\text {th }} \\
\text { floor }\end{array}$ & $\begin{array}{c}\text { Finished } \\
2016\end{array}$ & $\begin{array}{c}\text { Application of } \\
\text { window shading - } \\
\text { shading coefficient } \\
0.8\end{array}$ \\
\hline C & $\begin{array}{c}\text { Roller blinds } \\
\text { installation }- \\
1^{\text {st }}, 2^{\text {nd }}, 3^{\text {rd }} \text { floor }\end{array}$ & Finished & $\begin{array}{c}\text { Application of } \\
\text { window shading - } \\
\text { shading coefficient } \\
0.5\end{array}$ \\
\hline D & $\begin{array}{c}\text { Thermal } \\
\text { window film } \\
\text { installation }\end{array}$ & Planned & $\begin{array}{c}\text { Decreased heat and } \\
\text { light transmittance }\end{array}$ \\
\hline
\end{tabular}

\subsection{Calibration procedure}

The BSim model was calibrated to comply with the long-term measurements of indoor environment spanning 2 and half years. The calibration was carried out by changing the amount of unscheduled outdoor airflow into the thermal zone into exterior due to very detailed information from BMS and information about behaviour patterns. The value of outdoor airflow into the thermal zone is configured in BSim by setting the value of a basic air change $[/ \mathrm{h}]$. For the BSim simulation, we have tested value 0 to 10 with steps 0.1 . The most accurate value based on minimum average room air temperature difference (real measured temperature minus simulated temperature values) during the inspected period was $5.0 / \mathrm{h}$. Data in Fig. 5 (column bar graph of mean with value range whiskers) represent the absolute room air temperature difference for value of a basic air change of $5 / \mathrm{h}$ in hour time steps. Data are grouped into categories based on zone function - offices, conferences rooms, and top floor offices.

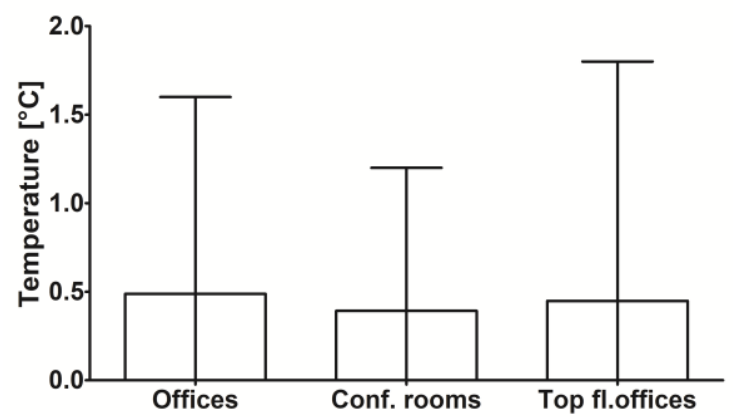

Fig. 5. Configuration of BSim model

According to Shapiro-Wilk normality test, KS normality test and D'Agostino and Pearson omnibus normality test, the data of temperature difference do not evince Gaussian distribution; therefore, median was used as a decisive statistical factor.

\section{Results}

\subsection{In situ monitoring}

The initial impulse for monitoring came from the tenants of the building expressing complaints about long-term overheating of the historic building during summer operation. Therefore, eight thermometers (data loggers) with measurement step 15 minutes were set up to monitor temperatures and humidities over a summer periods of 2016 and 2017 (from the $21^{\text {st }}$ of June to $23^{\text {rd }}$ of September). Furthermore, these measurements were accompanied with short-term monitoring of room air conditions with globe thermometers. The maximum temperature values in different working places according to work classes were determined in accordance with Czech [6, 7] and European legislation [8]. Additionally, this monitoring was used later to increase the quality of calibration of the building model.

Results of the in situ monitoring show that operative temperature $\left(t_{o}\right)$ and relative humidity $\left(R_{h}\right)$ in the building met the requirements of local legislation practically the entire measuring period with some shortterm (maximum 3 hours) exceptions. The minimum average operative workplace temperature $20{ }^{\circ} \mathrm{C}$ and maximum average operative temperature $27{ }^{\circ} \mathrm{C}$ were selected according to work class I for air-conditioned 
spaces based on latest Government Regulation ("Work mostly in a sitting position with low whole-body physical activity, office administrative work, monitoring activities, typing work, PC work, laboratory work, assembling and sorting of small light items"). Likewise, in case of relative air humidity, the lower limit is $30 \%$ and the upper limit is $70 \%$ for work class I for conditioned work places.

The results shown in Table 3 illustrate percentage of records within 15-minute step within and beyond the required limits for all entries.

Table 3. Results of in situ monitoring

\begin{tabular}{|l|c|c|c|c|}
\hline \multicolumn{1}{|c|}{$\begin{array}{c}\text { Room } \\
\text { type }\end{array}$} & $\begin{array}{c}\boldsymbol{t}_{\boldsymbol{o}} \\
\text { within } \\
\text { limits }\end{array}$ & $\begin{array}{c}\boldsymbol{t}_{\boldsymbol{o}} \\
\text { beyond } \\
\text { limits }\end{array}$ & $\begin{array}{c}\boldsymbol{R}_{\boldsymbol{h}} \\
\text { within } \\
\text { limits }\end{array}$ & $\begin{array}{c}\boldsymbol{R}_{\boldsymbol{h}} \\
\text { beyond } \\
\text { limits }\end{array}$ \\
\hline $\begin{array}{l}\text { Conference } \\
\text { rooms }\end{array}$ & $96.3 \%$ & $3.7 \%$ & $98.9 \%$ & $1.1 \%$ \\
\hline Offices & $96.8 \%$ & $3.2 \%$ & $99.6 \%$ & $0.4 \%$ \\
\hline $\begin{array}{l}\text { Offices in } \\
\text { top floor }\end{array}$ & $98.1 \%$ & $1.9 \%$ & $99.6 \%$ & $0.4 \%$ \\
\hline
\end{tabular}

The following Tukey boxplot (Fig. 6) graphically depicts data logger groups through quartiles during summer working days and hours in 2016 and 2017. The bottom and the top of the box are the first and the third quartiles; the band inside the box is median. The lowest datum represents $1.5 \mathrm{IQR}$ of lower quartile, the highest datum 1.5 IQR of the upper quartile.

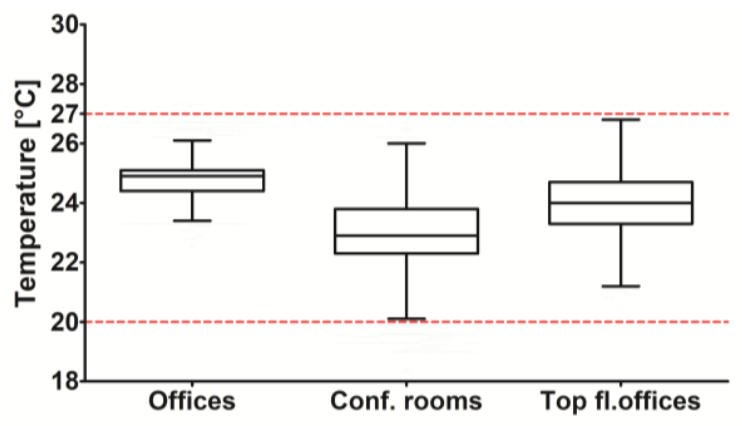

Fig. 6. Boxplot depicting room air temperatures in room types groups during working time in summer periods 2016 and 2017

\subsection{Retrofit measures}

After the calibration of the building model, the effect of retrofit measures on heating and cooling demand of the building was investigated using tsbi5 thermal simulation in BSim. We assumed that the geometrical model, material properties, internal thermal gains and losses, outdoor conditions (local TMY data), heating and cooling power, and building technology setups including schedules are same in all variants. Therefore, the parameters reflecting the retrofit measures are the only modified input values (see Table 2). First, we simulated the state with operation of only one cooling unit (reflecting situation in June and July 2016 when the second unit was under maintenance) - the scenario "Half $\mathrm{P}$ ". The scenario " $\mathrm{A}$ " represents condition after resumed operation of the second cooling unit, the scenario " $\mathrm{B}$ " application of outdoor sun shading elements in the top floor of the building, and the scenario " $\mathrm{C}$ " installation of roller blinds in the remaining windows. The scenarios "B" and " $\mathrm{C}$ " are investigated always together with resumed cooling power ("A+B", " $\mathrm{A}+\mathrm{C}$ "). The current situation of the building is covered within the scenario " $\mathrm{A}+\mathrm{B}+\mathrm{C}$ " (the resumed power and installation of both shading measures). The most cooling energy saving scenario " $\mathrm{A}+\mathrm{B}+\mathrm{C}+\mathrm{D}$ " adds installation of thermal window films on windows facing Wenceslas Square (the southeast façade).

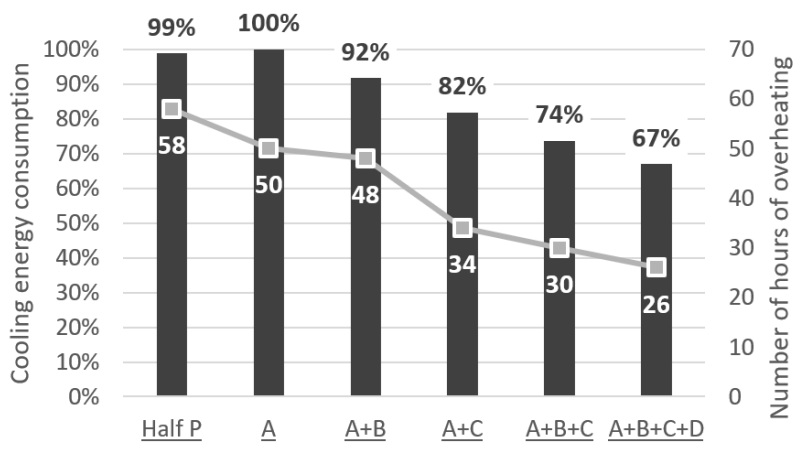

Fig. 7. Cooling energy saving measures - percentage of cooling energy saved and number of hours of overheating

Our year-long simulations show that the shading elements have important effect on cooling demands even in these types of buildings. Fig. 7 illustrates amount of energy for cooling saved after application the aforementioned scenarios and number of hours during which the building (any of the zones) is overheated. Additionally, for the simulation study, we considered combined limits with work class I and IIa - minimum temperature $20{ }^{\circ} \mathrm{C}$ and maximum $26^{\circ} \mathrm{C}$. The scenario "Half $\mathrm{P}$ " is actually almost identical from the energy saving point of view as scenario "A", however the number of hours of overheating is higher. It indicates that the alteration and optimization of control strategies for cooling (e.g. efficient night precooling) could lead to reduction of energy consumption. Except of reconfiguration and adjustments of control strategies of various systems and minor technical adjustments of building technologies, which will be investigated in the follow-up research, the shading elements are the only major cooling energy saving measures, which can be used for this historic building due to its current historic preservation.

\subsection{IPCC scenarios}

The main objective of chapter was to find out the maximum cooling and heating demand for this building using TMY (typical meteorological year) data and compare these demands with the maxima based on scenarios A1B and A2. For this purpose, the cooling and heating power was set as unlimited with no change to the control strategies and schedules.

Moreover, we wanted to provide information to the owner of the building whether the current installed cooling capacity would be sufficient considering the global climate change scenarios. 
The monthly demands needed for cooling and heating in every month of the simulated year are shown in Fig. 8.

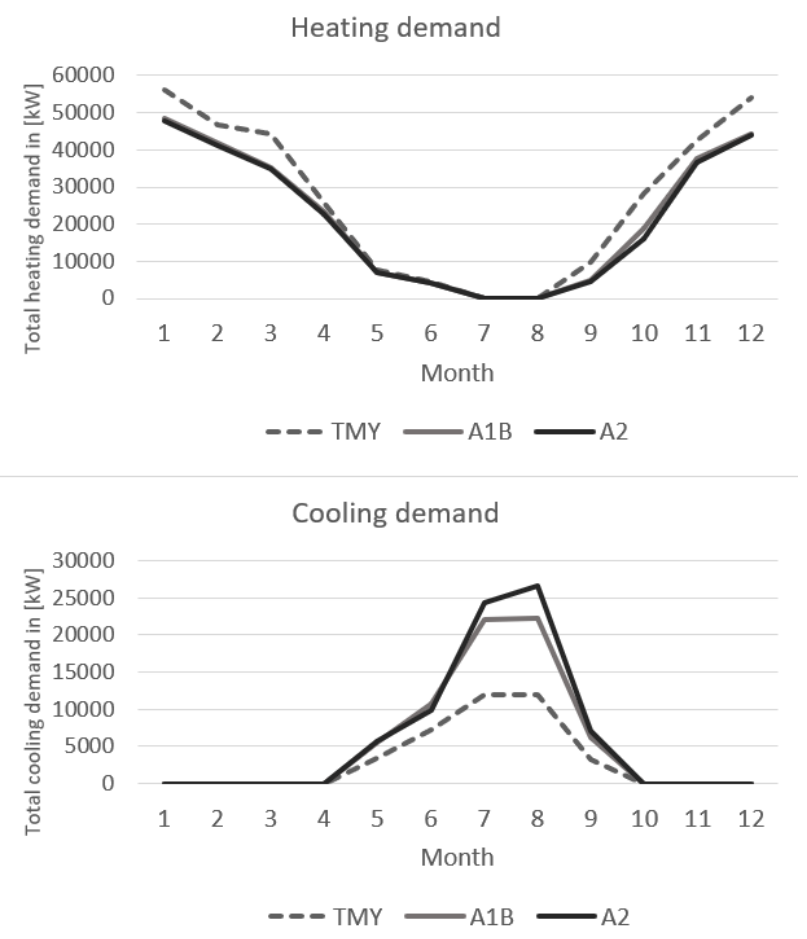

Fig. 8. Energy demand for heating and cooling per month

Naturally, after applying two global climate change scenarios from IPPC report, the heating demand is reduced but the cooling demand is increased significantly. The monthly cooling demand in June is increased by $83.7 \%$ for scenario A1B and $102.9 \%$ for scenario A2. In August, the monthly cooling demand is increased by $86.0 \%$ for scenario A1B and $123.2 \%$ for scenario A2.

The overall annual heating and cooling demand is shown in Fig. 9. The heating demand is lower for both A1B and A2 scenarios, but the cooling demand is significantly higher - A2 scenario evinces nearly double the cooling yearly demand.

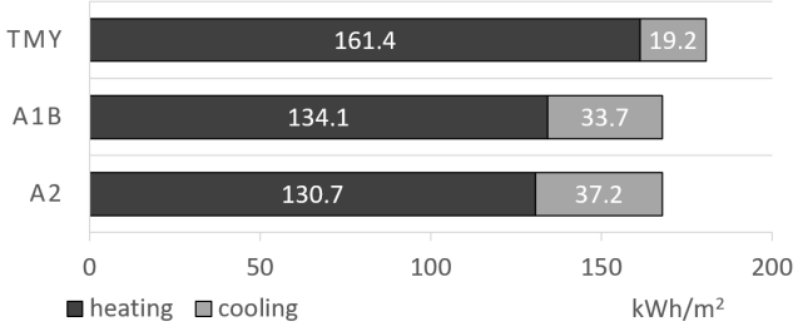

Fig. 9. Total annual heating and cooling demand per unit floor area

The last part of our study investigated sufficiency of installed cooling capacity not only for the current state of the building, but also within the change of weather conditions due to global climate change. For this part of the study, we used the current state of the building "A+B+C" state and only the weather data were modified. We wanted to achieve temperatures within the same limits as during the monitoring described in chapter 5.2. - minimum temperature $20{ }^{\circ} \mathrm{C}$ and maximum temperature $26^{\circ} \mathrm{C}$ in all zones.

While the current state of the building and building technologies provides optimal working conditions with only $2.9 \%$ recorded temperatures beyond limits for working cur measured with 15-minute step over period of two years, gradual increase of outside temperatures will lead to increased requirements on cooling systems. The number of hours beyond room operative temperature limits using simulations with TMY data is 30. However, the results of simulations carried out with modified weather data set according to A1B and A2 scenarios point out to limitations of the current cooling system setup and control strategy in the examined building. The number of hours beyond room operative temperature limits with $\mathrm{A} 1 \mathrm{~B}$ weather data set is 502 and with A2 data set is 744 .

\section{Conclusion}

The building sector, both residential and commercial, contributes towards overall energy consumption between $20 \%$ and $40 \%$ in developed countries. In European Union, buildings are responsible for $40 \%$ of energy consumption exceeding other major sectors such as transport and industry. While new buildings must fulfil regulations and therefore there can be considered as energy-efficient, many older buildings remain highly energy demanding. However, the amount of possible refurbishment methods is often significantly limited due to increased protection.

This work introduces the case study of a historic building. This historic object is being continuously monitored since building tenant's claims of overheating. These complains were directly addressed and refurbishment was made in summer 2016. The results of in situ monitoring are analysed and proves the minimal tendency of the building to overheating. The long-term monitoring served also for calibration purposes. The effect of cooling energy saving measures was investigated to provide information about efficiency of the planned retrofit measures. Each of the measures shows important cooling energy saving effect, especially considering all the limitations for possible changes in the building - no change of façade nor internal walls is allowed. In the second part the study, the impact of global climate change on energy demand of this examined building was investigated. As expected, the heating demand will be reduced, and cooling demand will increase. However, the increase of cooling demand in climate conditions of Central Europe for historic buildings can represent a significant problem - in many of these buildings there is no cooling system installed and its installation is problematic due to the historic preservation of the building. In case of this examined building, the yearly cooling demand is almost doubled using the modified TMY data with A2 climate change scenario. Although there is cooling system installed in the building with sufficient capacity, changes to the current setup will likely have to be made as described in the last part of the study. 


\section{Acknowledgment}

This contribution has been supported by project reg.no. LO1408 "AdMaS UP - Advanced Building Materials, Structures and Technologies" and co-funded by the "Austrian Federal Ministry of Science, Research and Economy" and as part of the funding program "COIN".

\section{References}

1. C. Brereton. The Repair of Historic Buildings, 1-76, (1991)

2. M. Jaggs, J. Palmer. Energy and Buildings, 31(2), 97-101, (2000)

3. Chapter 2: Evaluation of IPCC's Assessment Processes, IAC 2010, 16, (2010)

4. M.L. Parry, O. F. Canziani, et al., IPCC AR4 WG2., Climate Change 2007: Impacts, Adaptation and Vulnerability, (2007)

5. K.B. Wittchen, K. Johnsen, K. Grau. BSim 2002User's Guide, (2002).

6. Nařízení vlády č. 361/2007 Sb, (2007)

7. Nařízení vlády č. 93/2012 Sb, (2012).

8. Council Directive 89/654/EEC, (1989) 